Original Article

\title{
VIRUS STATUS, VARROA LEVELS, AND SURVIVAL OF 20 MANAGED HONEY BEE COLONIES MONITORED IN LUXEMBOURG BETWEEN THE SUMMER OF 2011 AND THE SPRING OF 2013
}

\author{
Antoine Clermont ${ }^{1}$ \\ Matias Pasquali ${ }^{1}$ \\ Michael Eickermann ${ }^{1}$ \\ François Kraus ${ }^{2}$ \\ Lucien Hoffmann ${ }^{1}$ \\ Marco Beyer ${ }^{1 *}$ \\ ${ }^{1}$ Luxembourg Institute of Science and Technology (LIST), Department 'Environmental \\ Research and Innovation' (ERIN), 41, rue du Brill, L-4422 Belvaux, Luxembourg \\ ${ }^{2}$ Administration des Services Techniques de l'Agriculture, B.P. 1904, L-1019 Luxembourg, \\ Luxembourg \\ *corresponding author: marco.beyer@list.lu \\ Received 04 August 2014; accepted 26 February 2015
}

\begin{abstract}
A bstract
Twenty managed honey bee colonies, split between 5 apiaries with 4 hives each, were monitored between the summer of 2011 and spring of 2013. Living bees were sampled in July 2011, July 2012, and August 2012. Twenty-five, medium-aged bees, free of varroa mites, were pooled per colony and date, to form one sample. Unlike in France and Belgium, Chronic Bee Paralysis Virus (CBPV) has not been found in Luxembourg. Slow Bee Paralysis Virus (SBPV) and Israeli Acute Paralysis Virus (IAPV) levels were below detection limits. Traces of Kashmir Bee Virus (KBV) were amplified. Black Queen Cell Virus (BQCV), Varroa destructorVirus-1 (VDV-1), and SacBrood Virus (SBV) were detected in all samples and are reported from Luxembourg for the first time. Varroa destructor MaculaLike Virus (VdMLV), Deformed Wing Virus (DWV), and Acute Bee Paralysis Virus (ABPV) were detected at all locations, and in most but not all samples. There was a significant increase in VDV-1 and DWV levels within the observation period. A principal component analysis was unable to separate the bees of colonies that survived the following winter from bees that died, based on their virus contents in summer. The number of dead varroa mites found below colonies was elevated in colonies that died in the following winter. Significant positive relationships were found between the log-transformed virus levels of the bees and the log-transformed number of mites found below the colonies per week, for VDV-1 and DWV. Sacbrood virus levels were independent of varroa levels, suggesting a neutral or competitive relationship between this virus and varroa.
\end{abstract}

Keywords: Apis mellifera, honey bee colony mortality, honey bee viruses, Varroa destructor, varroa-virus interactions.

\section{INTRODUCTION}

The European honey bee, Apis mellifera L., is one of the most important pollinators in agriculture (Gallai et al., 2009). Elevated losses of managed honey bee colonies were recently reported from the USA (vanEngelsdorp et al., 2012) and most countries of Europe (Potts et al., 2010, van der Zee et al., 2014). Several reasons for the declining bee colony numbers are discussed including the use of insecticides, intensification of land use (Nicholls and Altieri, 2013), bee parasites (Genersch, 2010) and a decreasing number of beekeepers in some regions (Semkiw and Skubida, 2010). In Europe, the ectoparasitic mite Varroa destructor was identified as the most important threat to apiculture (Rosenkranz et al., 2010). The mite consumes hemolymphic fluid and was identified as a vector of ABPV, KBV, IAPV, 
DWV, VDV-1, SBPV, and VdMLV (de Miranda et al., 2013). Symptoms caused by DWV/VDV-1 infections include the deformation of the wings (Möckel et al., 2011), reduced life span of winter bees (Dainat et al., 2012), modified homing ability of forager bees (Li et al., 2013) and possibly a decreased fecundity of queens at high virus levels (Gauthier et al., 2011). For accurate virus diagnosis, molecular biology techniques are needed because asymptomatic bees are often infected as well (Chen et al., 2006; De Smet et al., 2012; Locke et al., 2012).

National surveys have found significant interactions between colony losses, mites, and associated viruses. In a German monitoring program, winter mortality was found to increase with varroa mite levels, which were linked with infections of DWV and ABPV (Genersch et al., 2010). In a French study, DWV, SBV, and ABPV were detected in mites and bees (Tentcheva et al., 2004). Danish studies described a decreased level of mites after varroa treatment, but measured an increased level of DWV titres over the season (Francis et al., 2013). De Smet et al. (2012) found that multiple infections with ABPV, BQCV, CBPV, DWV, SBV, and SBPV, in Northern Belgium, could be predicted from the prevalence of individual viruses, suggesting independent occurrence of the viruses.

A previous survey indicated that $16.8 \%$ of the managed honey bee colonies in Luxembourg were lost over the winter of $2010 / 2011$, and $21.8 \%$ over the winter of 2011/2012 (Clermont et al., 2014). In contrast to other surveys, a clear spatial pattern of losses was observed. For the most part, high colony losses were reported from the Northern municipalities of the country in both years surveyed. Since information on the virus status of managed honey bees in Luxembourg is scarce (Siede et al., 2005), samples from 20 Buckfast colonies that were monitored since 2011, were analysed for their content of selected viruses. The objectives of the present study were to establish an initial baseline of virus levels in selected Luxembourgish honeybee colonies, as well as to check how much virus infections, related to local varroa counts, contribute to the explanation of the regionally different colony loss rates observed in the experimental apiaries used in the present study.

\section{MATERIAL AND METHODS}

\section{Sampling locations}

Five apiaries with 4 colonies each were set up in the spring of 2011 (Fig. 1a). Bees were obtained from a local breeder, and thus reflected the regional disease load. The apiaries were located at Linger (0552'29.5“E 49³4'23.2”N, 298 m above mean sea level (AMSL)), Rolling (06¹8'42.1“E 49³3'05.8“ $\mathrm{N}$, $206 \mathrm{~m}$ AMSL), Lorentzweiler $\left(06^{\circ} 11^{\prime} 19.5^{\prime \prime} \mathrm{E}\right.$ $49^{\circ} 42^{\prime} 35.9^{\prime \prime} \mathrm{N}, 419 \mathrm{~m}$ AMSL), Reichlange (055ㄷㄴ $51.9^{\prime \prime} \mathrm{E} 49^{\circ} 46^{\prime} 25.4^{\prime \prime} \mathrm{N}, 298 \mathrm{~m}$ AMSL), and Heinerscheid $\left(06^{\circ} 07^{\prime} 09.2^{\prime \prime} \mathrm{E} 50^{\circ} 06^{\prime} 22.3^{\prime \prime} \mathrm{N}, 365 \mathrm{~m}\right.$ AMSL). Whenever a colony died, it was replaced with a new colony having a Buckfast queen. The new colony received a new number. For instance, colony number 5 in Heinerscheid was the replacement for colony number 1 that died in the first winter.

\section{Standardised aspects of the management of the experimental bee colonies}

In the spring of 2011, colonies with young Buckfast queens were selected for the monitoring. The strength of all colonies was standardised to 8 frames covered with bees just before winter oilseed rape anthesis (the average start date of winter oilseed rape flowering between 2007 and 2013 was the $23^{\text {rd }}$ of April). Dadant hives were used throughout. Following a discussion with representatives of the local beekeeper's association, a combination of varroa treatments was laid down that represented the local standard at that time. All colonies were treated with Thymovar ${ }^{\circledR}$ ( 3 platelets per hive) over a period of 4 weeks between the $15^{\text {th }}$ of July and the $15^{\text {th }}$ of August, following the last honey extraction. After 2 weeks, the first batch of Thymovar ${ }^{\circledR}$ was replaced with a new lot that remained in the hive for another 2 weeks. Oxalic acid (18 g dihydrate) diluted in $500 \mathrm{~mL}$ of tap water having a temperature of about $20^{\circ} \mathrm{C}+500 \mathrm{~g}$ of sucrose, was dribbled between the frames two weeks after the first frost event which occurred either in November or December. Approximately $5 \mathrm{~mL}$ of the solution were dribbled on each seam of bees. At each location, a volunteer beekeeper living close by was provided with a 'bee diary' that was used to write down special observations.

\section{Varroa sampling}

The debris that fell out of each colony, including dead varroa mites, was collected by the volunteer beekeepers in the first week of each month using varroa mite screen boards. The size of the boards was $33.5 \times 28.5 \mathrm{~cm}$. For samples containing $\leq 150$ mites, all mites were counted in the entomology laboratory of the Luxembourg Institute of Science and Technology. For samples containing more than 150 mites, the materials in the sample were mixed. 


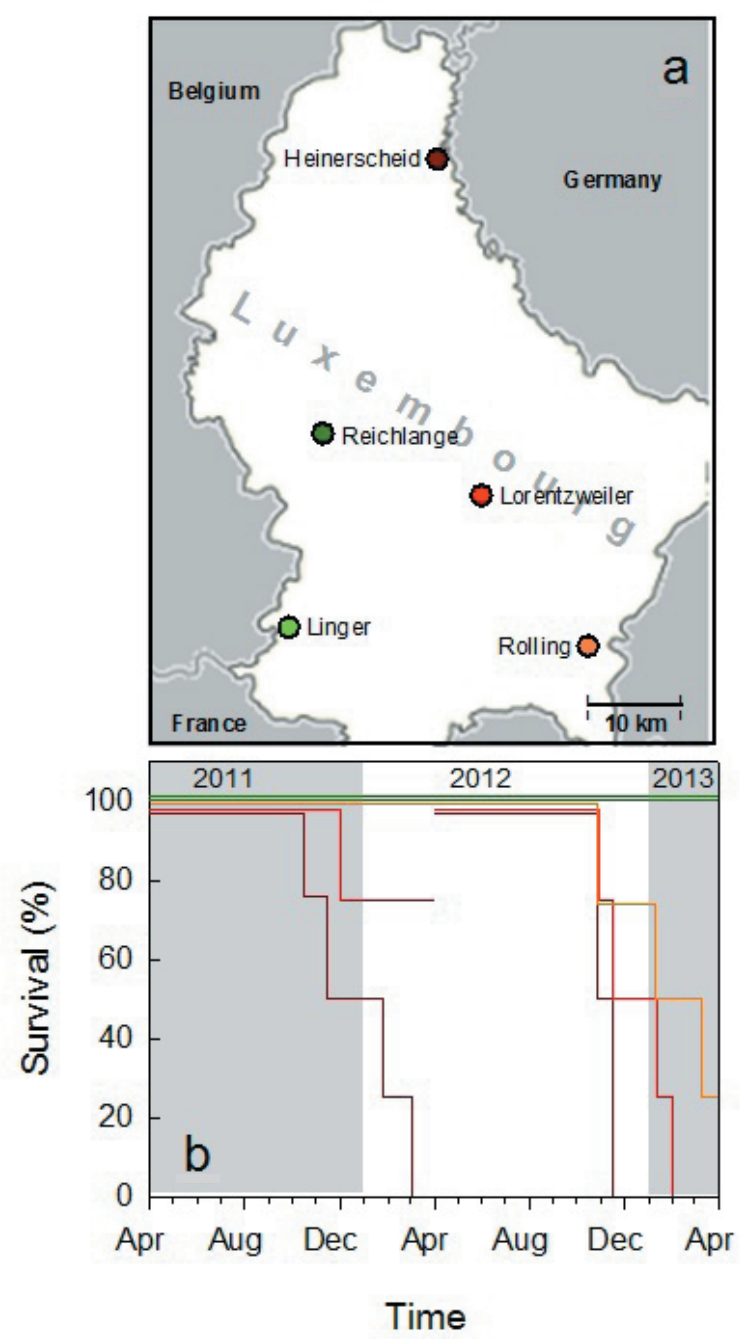

Fig. 1. Positions of the 5 experimental apiaries (a). Survival graph of the honey bee colonies monitored in the present study (b). Line colours correspond with the colours of the locations shown in (a). Colonies that died during the winter of 2011/2012 were replaced with new Buckfast colonies. The number of colonies was $n=4$ per location.

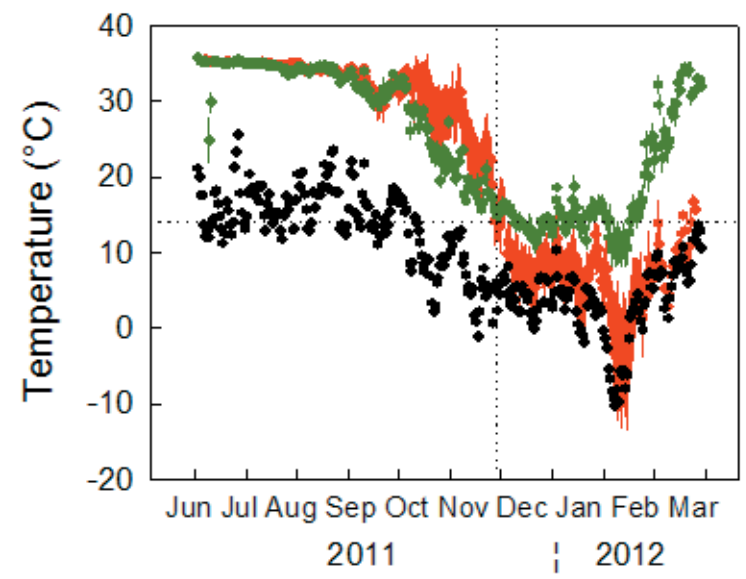

Fig. 2. Temperature time courses of bee colonies that died (red) and surviving bee colonies (green) over winter 2011/2012. Temperature sensors were mounted to the centre of bee colonies. Two temperature sensors were placed outside of the hives for comparison with external temperature (black symbols). Plot symbols represent medians of daily average temperatures, error bars represent standard errors. 
Table 1.

Location, colony number, sampling date, average number of viral genome copies per bee and the estimated date of colony death for all samples presented in the present study. Average virus contents per bee were calculated by dividing the cumulative virus content of 25 medium aged bees by 25

\begin{tabular}{|c|c|c|c|c|c|c|c|}
\hline \multirow{2}{*}{$\begin{array}{l}\text { Location, colony number, } \\
\text { sampling date }\end{array}$} & \multicolumn{6}{|c|}{ Average virus content per bee (copy numbers) } & \multirow{2}{*}{$\begin{array}{l}\text { Date of } \\
\text { collapse }\end{array}$} \\
\hline & VdMLV & DWV & ABPV & SBV & VDV-1 & $\mathrm{BQCV}$ & \\
\hline Heinerscheid, hive 5, 27.07.2012* & 72.76 & 2345255.26 & 24.01 & 2.12 & 87691549.95 & b.d.l. & $26 / 10 / 2012$ \\
\hline Heinerscheid, hive 5, 27.08.2012* & 54098.51 & 4560448.78 & b.d.l. & 2.07 & 173100579.62 & 36097.49 & $26 / 10 / 2012$ \\
\hline Heinerscheid, hive 6, 27.07.2012 & 152.43 & 202028.73 & 37070.29 & 3.17 & 3377401.00 & b.d.l. & $27 / 10 / 2012$ \\
\hline Heinerscheid, hive 6, 27.08.2012 & 83329.57 & 7448.86 & 33253.70 & 33.53 & 434316353.36 & 84.20 & $27 / 10 / 2012$ \\
\hline Heinerscheid, hive 7, 27.07.2012 & 342.98 & 75683120.82 & 1185.98 & 405927.54 & 384372007.68 & 521.73 & $16 / 11 / 2012$ \\
\hline Heinerscheid, hive 7, 27.08.2012 & 391.92 & 81324729.55 & 14642131.32 & 3495.32 & 109466880.69 & 68.95 & $16 / 11 / 2012$ \\
\hline Heinerscheid, hive 8, 27.07.2012 & 22587.90 & 24689161.15 & 55.62 & 389.19 & 415249024.23 & 1274.40 & $16 / 11 / 2012$ \\
\hline Heinerscheid, hive 8, 27.08.2012 & 24777.44 & 119460219.39 & 64836479.46 & 44879.12 & 153450961.05 & 8629.18 & $16 / 11 / 2012$ \\
\hline Linger, hive $1,11.07 .2011^{*}$ & b.d.I. & 1186.35 & 2514.26 & 159212.04 & 14210.83 & b.d.l. & survived \\
\hline Linger, hive 1, 18.07.2012* & b.d.l. & 8493.84 & 609.05 & 113230.06 & 21157645.61 & 3516.21 & vived \\
\hline Linger, hive 1, 28.08.2012* & b.d.I. & 414.95 & 1020.87 & 61.96 & 999952.97 & b.d.l. & survived \\
\hline Linger, hive 2, 11.07.2011* & b.d.I. & 1415.91 & 3548.98 & 411.14 & 7137304.41 & b.d.l. & vived \\
\hline Linger, hive 2, 18.07.2012* & 397.97 & 620116.36 & 24043958.42 & 69181.62 & 143736277.95 & 6206.31 & vived \\
\hline Linger, hive 2, 28.08.2012* & b.d.l. & 10679339.38 & 7810961.66 & 9.13 & 74404729.32 & 12040.30 & vived \\
\hline Linger, hive $3,11.07 .2011^{*}$ & b.d.l. & 836.85 & 4390.40 & 318338.70 & 697299.68 & b.d.l. & survived \\
\hline Linger, hive $3,18.07 .2012^{*}$ & b.d.l. & 28333.03 & 3887.42 & 306282.71 & 11983286.36 & b.d.l. & survived \\
\hline Linger, hive $3,28.08 .2012^{\star}$ & b.d.l. & 1600.63 & 459.71 & 21404.50 & 48094282.45 & 2608.30 & survived \\
\hline Linger, hive $4,11.07 .2011^{*}$ & b.d.l. & 19073.81 & 7576.67 & 1580.88 & 415132.54 & b.d.l. & survived \\
\hline Linger, hive 4, 18.07.2012* & 112.68 & 2134.87 & 184.54 & 33980.18 & 20979153.78 & 1549.69 & survived \\
\hline Linger, hive 4, 28.08.2012* & 91.16 & 1113594.06 & 211.34 & 51.85 & 71965932.08 & b.d.l. & vived \\
\hline Lorentzweiler, hive 1, 18.07.2011 & $\begin{array}{l}\text { b.d.l. } \\
\text { b. }\end{array}$ & 1178.14 & 32552.97 & 6326.56 & 4707867.13 & $\begin{array}{l}\text { b.d.l. } \\
\text { b. }\end{array}$ & $02 / 12 / 2011$ \\
\hline Lorentzweiler, hive 2, 18.07.2011 & b.d.l. & 246.84 & 557.75 & 4956.53 & 1124585.53 & b.d.l. & $13 / 11 / 2012$ \\
\hline Lorentzweiler, hive 2, 17.07.2012 & b.d.l. & 11646.35 & 151.25 & 47.88 & 42314784.16 & b.d.l. & $13 / 11 / 2012$ \\
\hline Lorentzweiler, hive 2, 21.08.2012 & b.d.I. & 406331.41 & 3942525.55 & 6.25 & 6625531.73 & b.d.l. & 12012 \\
\hline Lorentzweiler, hive 3, 18.07.2011 & b.d.l. & 706.32 & 234.65 & 126008.80 & 10520039.46 & b.d.l. & 2012 \\
\hline Lorentzweiler, hive 3, 17.07.2012 & 698.95 & 27366723.72 & 605.92 & 8605.28 & 150423052.38 & b.d.l. & 2012 \\
\hline Lorentzweiler, hive 3, 21.08.2012 & 5308.42 & 151083550.60 & 855.71 & 4.39 & 122749113.56 & 386.30 & 2012 \\
\hline Lorentzweiler, hive 4, 18.07.2011 & 546.98 & 318.17 & 481.16 & 57000.02 & 47766124.19 & b.d.l. & 2013 \\
\hline e 4, 17.07.2012 & b.d.I. & 742.52 & 32.74 & 1527.14 & 6596018.93 & b.d.l. & 2013 \\
\hline 4, 21.08.2012 & 257.89 & 19226.38 & 3170.52 & 2.96 & 51251242.93 & b.d.l. & 2013 \\
\hline $5,17.07 .2012$ & b.d.I. & 137842.14 & 76.64 & 78274.73 & 1454002.96 & 966.06 & 2013 \\
\hline e 5,21.08.2012 & b.d.l. & 349137.92 & 146987.89 & 9.98 & 224.53 & 124.04 & 2013 \\
\hline $1,26.07 .2011$ & b.d.l. & 6016.98 & 1889.22 & 30.56 & 91016962.28 & 125.59 & ved \\
\hline $1,19.07 .2012^{\star}$ & b.d.l. & 1751057.86 & 162.56 & 7.48 & 2070197.65 & b.d.l. & vived \\
\hline Reichlange, hive 1, 31.08.2012* & 2920.05 & 142451.20 & 5811657.77 & 20.21 & 450430047.52 & 1576.03 & vived \\
\hline $2,26.07 .2011$ & 628.59 & 3442.52 & 1598.30 & 3802.06 & 35309712.46 & 1344.97 & ived \\
\hline Reichlange, hive 2, 19.07.2012* & 218.89 & 16727.06 & 337.73 & 213.73 & 4202445.13 & b.d.I. & jived \\
\hline Reichlange, hive 2, 31.08.2012* & 41894.25 & 130334.88 & 851.65 & 2.77 & 453123719.52 & b.d.l. & survived \\
\hline Reichlange, hive 3, 26.07.2011 & 257.89 & 92859.71 & 2148058.46 & 11.13 & 54989569.14 & b.d.I. & survived \\
\hline Reichlange, hive 3, 19.07.2012* & 112.08 & 4280.18 & 1148.19 & 751780.52 & 41734018.20 & b.d.l. & survived \\
\hline Reichlange, hive 3, 31.08.2012* & 275.20 & 2456.76 & 293.48 & 34.23 & 164187730.35 & b.d.l. & survived \\
\hline Reichlange, hive 4, 26.07.2011 & 2099.78 & 111439.20 & 2867.82 & 560.47 & 34626822.26 & b.d.l. & survived \\
\hline Reichlange, hive 4, 19.07.2012* & 619.92 & 6268.96 & 582.28 & 14.51 & 13740968.77 & b.d.l. & survived \\
\hline Reichlange, hive 4, 31.08.2012* & 39614.35 & 2477117.62 & 219655.45 & 3.35 & 669490240.93 & 761.62 & ived \\
\hline Rolling, hive 1, 22.07.2011 & b.d.l. & b.d.l. & 859.84 & 130.70 & 6129.23 & b.d.l. & survived \\
\hline Rolling, hive 1, 20.07.2012 & 118.05 & 2423.07 & 559.68 & 61.63 & 2526503.82 & 1749.77 & $07 / 01 / 2013$ \\
\hline Rolling, hive 1, 29.08.2012 & 86988.23 & b.d.l. & 489552.31 & 7.40 & 161664254.46 & b.d.l. & $07 / 01 / 2013$ \\
\hline Rolling, hive 2, 22.07.2011 & 10817.99 & b.d.l. & 1372.83 & 672281.74 & 1845833.07 & 169.87 & survived \\
\hline $2,20.07 .2012$ & b.d.I. & 2435.85 & 11690.75 & 880792.91 & 3381155.59 & 134.85 & ived \\
\hline Rolling, hive 2, 29.08.2012 & b.d.I. & b.d.I. & 212.35 & 1654.33 & 230238.14 & 116.38 & ived \\
\hline Rolling, hive 3, 22.07.2011 & 152.58 & 1439.30 & 91.34 & 337594.74 & 17461.15 & b.d.l. & $07 / 03 / 2013$ \\
\hline Rolling, hive 3, 20.07.2012 & 76.56 & 5382.23 & 424.89 & 3393.81 & 24322905.50 & b.d.l. & $07 / 03 / 2013$ \\
\hline Rolling, hive 3, 29.08.2012 & 1567.77 & 425.77 & 1279.28 & 12.06 & 1286689.61 & b.d.l. & $07 / 03 / 2013$ \\
\hline Rolling, hive 4, 22.07.2011* & 73.04 & 517.82 & 255.24 & 49.93 & 173470.67 & b.d.l. & 24/10/2012 \\
\hline Rolling, hive 4, 20.07.2012 & 15014.86 & 787.30 & 11807.10 & 62.11 & 9389306.14 & b.d.l. & $24 / 10 / 2012$ \\
\hline Rolling, hive 4, 29.08.2012 & 11723.30 & 427489.84 & 43538122.72 & 5661.48 & 208840253.90 & 5132.98 & $24 / 10 / 2012$ \\
\hline
\end{tabular}

b.d.l. = below detection limit ( 2 to 326 viral genome copy numbers per bee, depending on virus)

*No varroa sample available for the period of virus sampling.

VdMLV - Varroa destructor Macula-Like Virus; DWV - Deformed Wing Virus; ABPV - Acute Bee Paralysis Virus; SBV - SacBrood Virus; VDV-1 -

Varroa destructor Virus-1; BQCV - Black Queen Cell Virus. 
List of primers, melting temperatures $\left(\mathrm{T}_{\mathrm{m}}\right)$ of dissociation curves, and primer targets.

The $A$. mellifera actin primer sequence was taken from Scharlaken et al. (2008), and all virus primer sequences from Locke et al. (2012)

\begin{tabular}{|c|c|c|c|}
\hline Forward primer & Reverse primer & $\mathrm{T}_{\mathrm{m}}$ & Target \\
\hline AMACTIN 1 TGCCAACACTGTCCTTTCTG & AMACTIN 2 AGAATTGACCCACCAATCCA & 80.7 & $\begin{array}{c}\text { Apis mellifera } \\
\text { actin }\end{array}$ \\
\hline $\begin{array}{c}\text { Abpv-F6548 } \\
\text { TCATACCTGCCGATCAAG }\end{array}$ & $\begin{array}{c}\text { kiAbpv-b6707 } \\
\text { CTGAATAATACTGTGCGTATC }\end{array}$ & 81.0 & ABPV \\
\hline $\begin{array}{c}\text { BqCvq-F7893 } \\
\text { AGTGGCGGAGATGTATGC }\end{array}$ & $\begin{array}{c}\text { BQCVq-B8150 } \\
\text { GGAGGTGAAGTGGCTATATC }\end{array}$ & 80.5 & BQCV \\
\hline $\begin{array}{c}\text { CBPV1q-F1818 } \\
\text { CAACCTGCCTCAACACAG }\end{array}$ & $\begin{array}{c}\text { CBPV1q-B2077 } \\
\text { AATCTGGCAAGGTTGACTGG }\end{array}$ & 84.0 & CBPV \\
\hline $\begin{array}{c}\text { DWV-F8668 } \\
\text { TTCATTAAAGCCACCTGGAACATC }\end{array}$ & $\begin{array}{c}\text { DWV-B8757 } \\
\text { TTTCCTCATTAATGTGTCGTTGA }\end{array}$ & 79.5 & DWV \\
\hline $\begin{array}{c}\text { IAPV-F6627 } \\
\text { CCATGCCTGGCGATTCAC }\end{array}$ & $\begin{array}{c}\text { kiAbpv-b6707 } \\
\text { CTGAATAATACTGTGCGTATC }\end{array}$ & 81.0 & IAPV \\
\hline $\begin{array}{c}\text { KBV-F6639 } \\
\text { CCATACCTGCTGATAACC }\end{array}$ & $\begin{array}{c}\text { kiAbpv-b6707 } \\
\text { CTGAATAATACTGTGCGTATC }\end{array}$ & 81.5 & KBV \\
\hline $\begin{array}{c}\text { SBVq-F3164 } \\
\text { TTGGAACTACGCATTCTCTG }\end{array}$ & $\begin{array}{c}\text { SBVq-b3461 } \\
\text { GCTCTAACCTCGCATCAAC }\end{array}$ & 80.3 & SBV \\
\hline $\begin{array}{c}\text { SBPV-F3177 } \\
\text { GCGCTTTAGTTCAATTGCC }\end{array}$ & $\begin{array}{c}\text { SBPV-B3363 } \\
\text { ATTATAGGACGTGAAAATATAC }\end{array}$ & 78.5 & SBPV \\
\hline $\begin{array}{c}\text { VDVF-1409 } \\
\text { GCCCTGTTCAAGAACATG }\end{array}$ & $\begin{array}{c}\text { DWV-B1806 } \\
\text { CTTTTCTAATTCAACTTCACC }\end{array}$ & 80.5 & VDV-1 \\
\hline $\begin{array}{c}\text { AmVdMLV-F } \\
\text { ATCCCTTTTCAGTTCGCT }\end{array}$ & $\begin{array}{c}\text { AmVdMLV-R } \\
\text { AGAAGAGACTTCAAGGAC }\end{array}$ & 86.5 & VdMLV \\
\hline
\end{tabular}

ABPV - Acute Bee Paralysis Virus; BQCV - Black Queen Cell Virus; CBPV - Chronic Bee Paralysis Virus; DWV - Deformed Wing Virus; IAPV Israeli Acute Paralysis Virus; KBV - Kashmir Bee Virus; SBV - SacBrood Virus; SBPV - Slow Bee Paralysis Virus; VdMLV - Varroa destructor Macula-Like Virus; VDV-1 - Varroa destructor Virus-1

Then a sub-sample representing $15 \%$ of the original mass was taken using a microbalance, and the number of mites was counted in the sub-sample. Subsequently, the number of mites in the total sample was estimated using this equation:

Total number of mites in the sample $=$ (total mass of the sample $\times$ number of mites in the sub-sample) / mass of the sub-sample

Sometimes, the periods of varroa sampling and bee sampling for virus analyses were not identical. The respective data sets were excluded from analysis when studying correlations between virus contents and varroa mites. Data sets, where appropriate varroa samples were missing, are marked with an asterisk in Table 1.

\section{Estimating the date of colony death}

One waterproof temperature logger (model HOBO UA-002-64, onset) was mounted into each hive as close to the centre of the bee colony as possible. Two loggers were mounted to trees or bushes in the shadow, at a distance of less than $5 \mathrm{~m}$ from the apiary. Time courses of internal and external temperature were plotted for each colony. Except for a short period with external temperatures as low as $-20^{\circ} \mathrm{C}$, temperatures of about $14^{\circ} \mathrm{C}$ were logged in the hives of surviving colonies over winter (Fig. 2). We therefore assumed, that a colony died the day when the temperature in the colony fell below $14^{\circ} \mathrm{C}$ and afterwards did not exceed external temperatures any more. Death or survival of each colony was confirmed by visual inspections in spring.

\section{Bee sampling and quantification of the virus load} Sampling for virus quantification was carried out in July and August, a time of year when peak loads have been previously reported for several viruses (Runckel et al., 2011). Approximately 100 living bees from each of the 4 hives of each of the 5 experimental apiaries were shaken from a frame located at the side of the hive, through a funnel, into perforated plastic bags to allow respiration. Sampling dates are given in Table 1. Bees were transported alive at $8-14^{\circ} \mathrm{C}$ in a cooling box. It took less than 90 minutes to transport the bees to the laboratory. The sampled bees were checked in the laboratory for viability, 
and then frozen in liquid nitrogen and stored at $-80^{\circ} \mathrm{C}$ until RNA extraction.

A total of 25 frozen adult workers free of varroa mites were pooled for each location and sampling period, and ground manually. Total RNA was extracted by using Qiagen Plant RNeasy kits, including DNase treatment, according to the manufacturer's recommendations. Two aliquots of RNA were quantified using a Nanodrop ND1000 spectrophotometer (Thermo Scientific), measuring the absorbance at $230 \mathrm{~nm}, 260 \mathrm{~nm}$ and $280 \mathrm{~nm}$. Quality was assessed using the RNA Nano 6000 assay on the Bioanalyzer 2100 (Agilent Technologies) RNA chip comparing profiles to previously defined standards (Winnebeck et al., 2010). RNA was then stored at $-80^{\circ} \mathrm{C}$ until use in rt-PCR.

Reverse transcription was carried out according to the manufacturer's recommendations (Invitrogen, USA) using random hexamers and Superscript ॥ enzyme on 2.5 micrograms of total RNA in 50 microliters. The following reaction conditions were used: 10 min at $25^{\circ} \mathrm{C}, 50$ min at $42^{\circ} \mathrm{C}$ for cDNA synthesis plus 15 min at $70^{\circ} \mathrm{C}$ for reverse transcription inactivation. Complementary DNA (final concentration $50 \mathrm{ng} /$ microliter) was conserved at $-80^{\circ} \mathrm{C}$. An aliquot was used for performing GPCR assays which was kept at $2^{\circ} \mathrm{C}$ during the processing days. Quantitative real-time PCR (qPCR) reactions were carried out using Mesa Green Low Rox Real-time PCR kits (Eurogenetec) on $30 \mathrm{ng}$ of total cDNA in the via7 (Applied Biosystem) PCR machine in fast mode. The following program was used: $2 \mathrm{~min}$ at $95^{\circ} \mathrm{C}$ followed by 40 cycles with $10 \mathrm{~s}$ at $95^{\circ} \mathrm{C}$ for denaturation and $30 \mathrm{~s}$ at $60^{\circ} \mathrm{C}$ for primer annealing, extension, and data collection. The amplification reaction was followed by a melting curve analysis to determine the specificity of the amplification products by incubating them for $60 \mathrm{~s}$ at $95^{\circ} \mathrm{C}$ and $60 \mathrm{~s}$ at $55^{\circ} \mathrm{C}$ and then reading the fluorescence at $0.5^{\circ} \mathrm{C}$ increments from $55^{\circ} \mathrm{C}$ to $95^{\circ} \mathrm{C}$. Primer specificity was verified by the presence of a single peak at the expected size (Dwight et al., 2011) in the melting curve.

A test on cDNA degradation was carried out comparing amplification efficiencies at the beginning and at the end of the experiment by amplifying bee actin.

Apis mellifera actin was selected as the gene to normalise the samples (Scharlaken et al., 2008). All primers used are listed in Table 2. The viruses tested were ABPV, SBV, VDV-1, BQCV, DWV, VdMLV, SBPV, CBPV, KBV, and IAPV. Linearity of the assay was monitored on 3 replicates, and PCR efficiencies were calculated for each experiment.
Three negative controls and a no-RT control were introduced in each reaction series to monitor nonspecific amplification due to contamination or DNA carryover. Standard curves were generated by amplifying cloned viral fragments (material kindly provided by Joachim R. de Miranda) through PCR followed by purification and quantification using both fluorometric and spectrophotometric quantification. Dilutions of $1: 10$, ranging from $5 \mathrm{ng}$ of target material to 5 to $10^{-9} \mathrm{ng}$ were selected, depending on the PCR efficiency (above 85\%) and PCR assay.

For each primer pair, PCR efficiency was calculated on standard curves using the formula based on regression slopes where efficiency $(E)$ of the different assays was: $E_{\text {assay }}=10^{-1 / \text { slope }}$. For quantitative calculation, a normalisation coefficient was calculated for each cDNA based on $A$. mellifera actin Cq amplification data. All other Cq values obtained from other primers were normalised to account for differences in extraction efficacy between samples. Mass quantification of the viral material per sample was calculated by resolving the regression equation derived from each primer amplification reaction.

\section{Data analysis and presentation}

The number of viral genome copies per bee was calculated using the reference Genebank sequence of each respective virus, and calculating the molecular weight of the amplified fragment uploading sequences to an online calculator tool Sequence Manipulation Suite. The number of copies per bee was obtained by multiplying the value by the Avogadro number (Pasquali et al., 2006) and dividing the amount by 25 (the number of bees sampled).

Virus contents expressed as the number of viral genome copies per bee as well as the varroa counts, were characterised by many small values and few large values. Log-transformation was necessary to obtain approximate Gaussian distributions and to stabilise variances. A small non-zero constant (minimum value observed for the respective virus divided by 2) was added to all values prior to logtransformation to avoid the loss of the values with virus contents of 0 , respectively below the detection limit, as was recommended by de Miranda et al. (2013). Effects of location, year, and sampling month on log-transformed virus contents were tested using the general linear model option of the statistical software package IBM SPSS version 19. Multiple comparisons of the virus content between locations or sampling times were carried out according to Tukey (IBM SPSS). Correlations between the logtransformed virus contents and the log-transformed 
m் बه

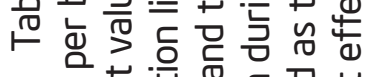

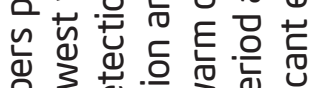

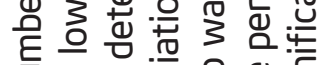

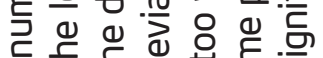
돵ㅎㅁ음 合

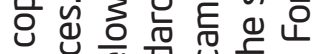

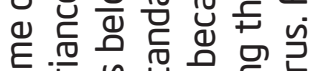

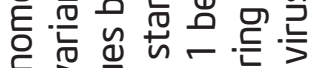

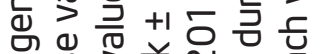

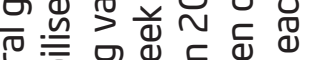

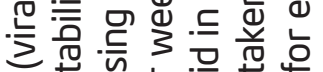

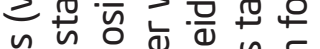
듣으믐든 巳ั

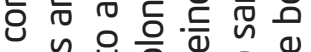

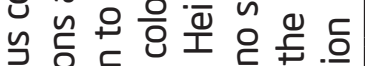
늑윽윽 증듀

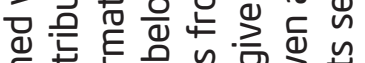

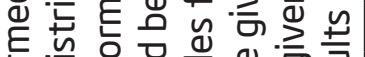

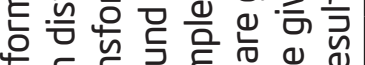

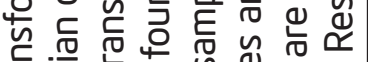

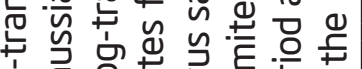

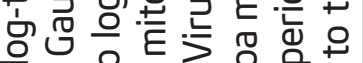
응유인

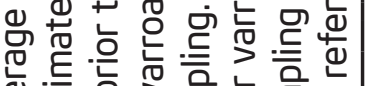

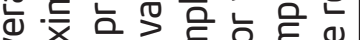
而合 는은

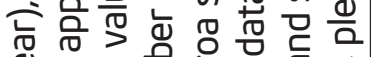

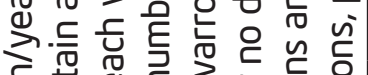
吕罚 등워

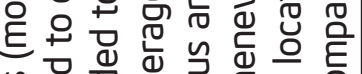

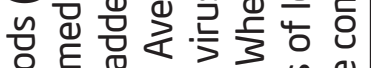

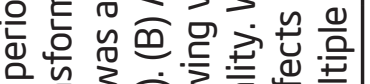
밍

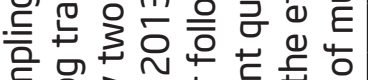

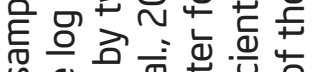

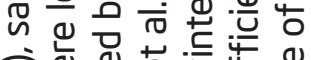

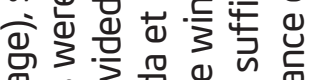

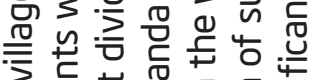

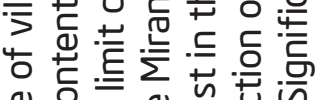

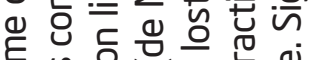

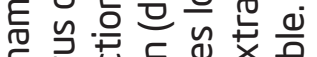

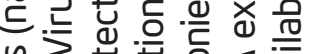

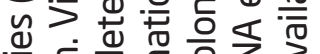

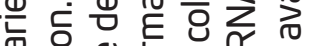

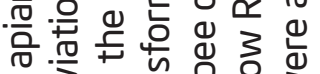

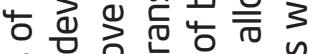

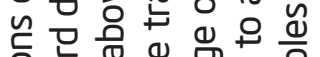

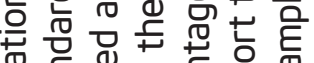

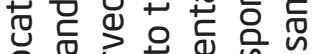

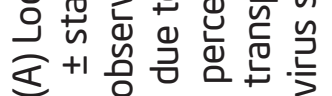

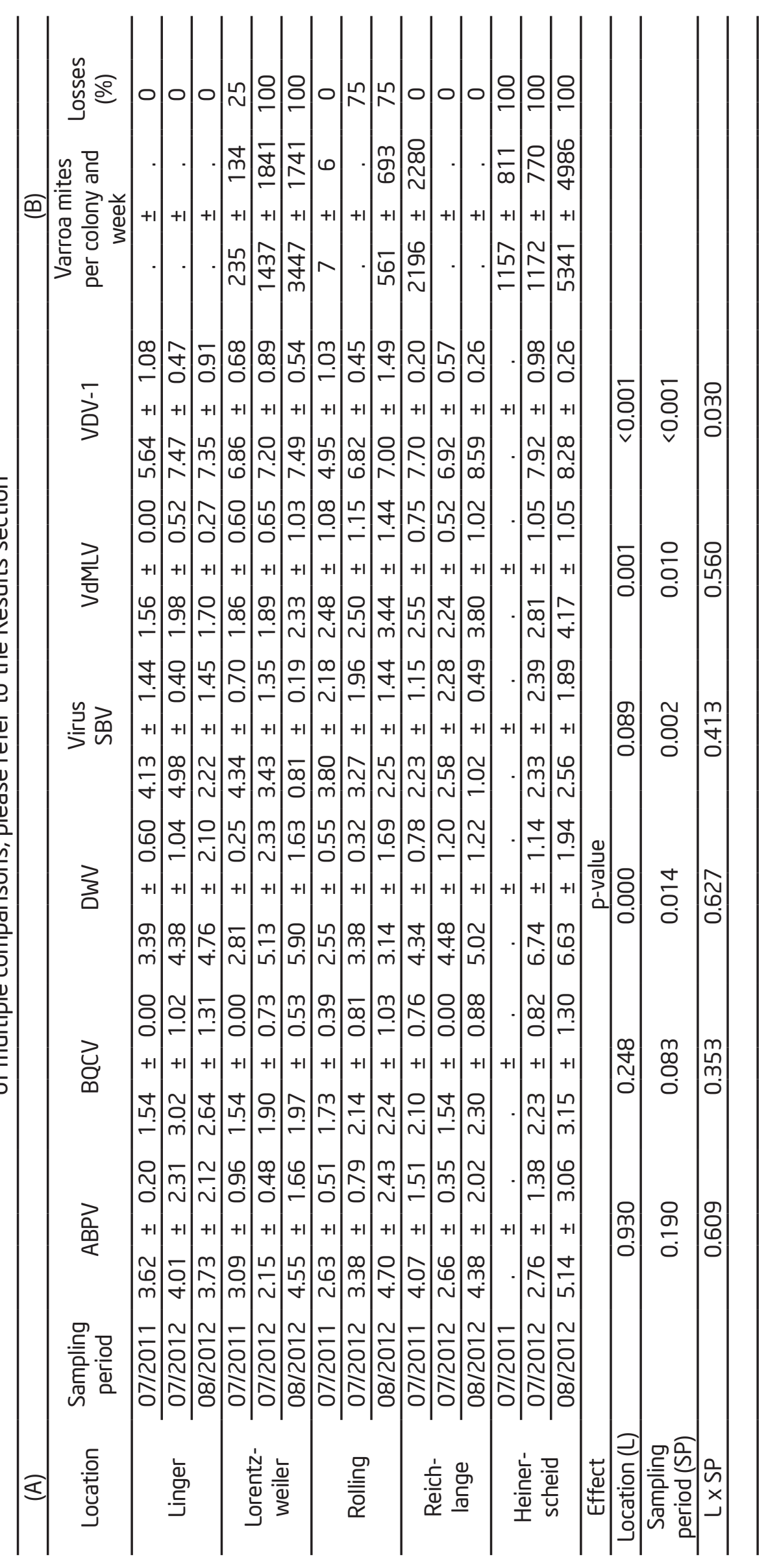


varroa counts were tested for significance $(p<0.05)$. Differences between the number of varroa mites found below colonies that survived the following winter and colonies that did not survive were studied using the non-parametric Mann-Whitney U-tests for each sampling period. Principal components (PCs) based on correlation matrices were extracted from the log-transformed bee virus contents. The first two PCs explaining most of the variance within the virus data were plotted against each other to check if colonies that survived and colonies that died in the following winter could be distinguished based on their virus patterns in summer.

\section{RESULTS}

\section{Survival of colonies}

Temperatures in the hives of the surviving colonies increased between the end of February and the beginning of March, while temperatures in dead colonies remained at the level of the temperature outside of the hive (Fig. 2). In the Northern Heinerscheid location, all the colonies were lost in both years (Fig. 1b). At the Linger and Reichlange (East) locations, no colonies were lost (Fig. 1b). At Lorentzweiler, in the centre of the country, one out of four colonies was lost over the 2011/12 winter, while all the colonies were lost in the following winter (Fig. 1b). At Rolling (South) no losses were observed in the first winter, while 3 out of 4 colonies were lost over the 2012/2013 winter (Fig. 1b). The total loss rates experienced in the experimental apiaries were $25 \%$ and $55 \%$ over the $2011 / 12$ and $2012 / 13$ winters, respectively. Five colonies were lost in October, four were lost in November and January, respectively, two colonies were lost in March and one colony was lost in December (Fig. 1b, Tab. 1).

\section{Virus levels - General}

CBPV, IAPV, and SBPV could not be detected as no amplification was obtained from any sample for these viruses. Kashmir bee virus levels were below the linear detection limit as well, but for two samples traces of the band being specific for KBV were amplified after 35 cycles (below linear dilution curve). These findings suggest the presence of traces of the virus.

Averages \pm standard deviations of log-transformed virus contents are shown in Table 3 for each location and sampling period. For the results of individual colonies, please see Table 1. At all locations, ABPV and BQCV were found at a median level of $1.19 \times$ $10^{3}$ and 69 viral genome copies per bee, respec- tively. There were no significant differences among locations or sampling periods. Effects of the interaction between the location and the sampling period were non-significant for all viruses with p-values ranging from 0.353 to 0.609 , except for VDV-1, where it was significant at $p=0.030$ (Tab. 3)

\section{Temporal dynamics of virus load}

Sacbrood virus was detected at median levels of $4.38 \times 10^{3}$ and $2.46 \times 10^{3}$ viral genome copies per bee in July 2011 and 2012, respectively. Sacbrood virus levels decreased significantly $(p=0.004)$ to about 16 viral genome copies per bee in August 2012. Varroa destructor virus-1 levels significantly $(p=0.0001)$ increased from $3.27 \times 10^{6}$ viral genome copies per bee in July 2011 to $17.36 \times 10^{6}$ viral genome copies per bee in July 2012 ( $p=0.008)$. There was a significant increase in DWV levels: from $1.18 \times 10^{3}$ viral genome copies per bee in July 2011 to $1.42 \times 10^{4}$ viral genome copies per bee in July 2012 and to $2.4510^{5}$ viral genome copies per bee in August 2012.

\section{Spatial differences of virus load}

Virus levels were not significantly different ( $p>0.123$ ) among locations except for DWV, VDV-1, and VdMLV. There were significantly higher DWV levels at Heinerscheid compared to all the other locations (Tab. 3). There were significantly lower VdMLV levels at Linger compared to Reichlange and Heinerscheid and significantly higher at Heinerscheid compared to Linger and Lorentzweiler (Tab. 3). There were significantly lower VDV-1 levels at Rolling compared with Reichlange and Heinerscheid, and significantly higher at Heinerscheid compared with Rolling and Linger (Tab. 3).

\section{Varroa counts}

Over the winter of $2011 / 12$, five colonies died, while 15 survived. Significantly more varroa mites were found between August and October in colonies that died in the following winter compared to colonies that survived (Fig. 3A). Over the winter of 2012/13, eleven colonies died and 9 colonies survived. Only those beekeepers in charge of the colonies that died collected varroa mites in the winter of 2012/13. Hence, Fig. 3B shows the difference in the number of fallen varroa mites between colonies that died early and colonies that died late. Significantly more varroa mites were found below colonies that died in the same year between July and August compared to colonies that died in the spring of the following year. However, the data shown in Fig. 3 were pooled from 


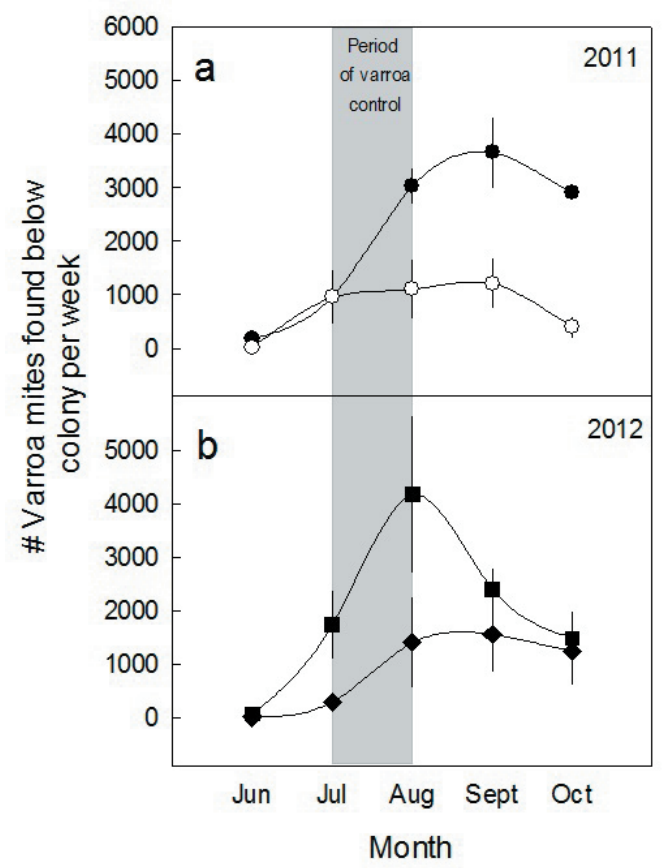

Fig. 3. (A) Time course of the number of varroa mites found per week below managed honey bee colonies that died $(\bullet)$ and survived ( $(\circ)$ over the winter of 2011/2012. (B) Time course of the number of varroa mites found per week below managed honey bee colonies that died early (between October and December 2012,") and late (between January and March $2013, \$$ ). Plot symbols represent the means; error bars - the standard error of the mean. The number of replicates ranged from 2 - 6. Points were connected with a spline interpolation. Periods of varroa treatments are marked with grey shading.

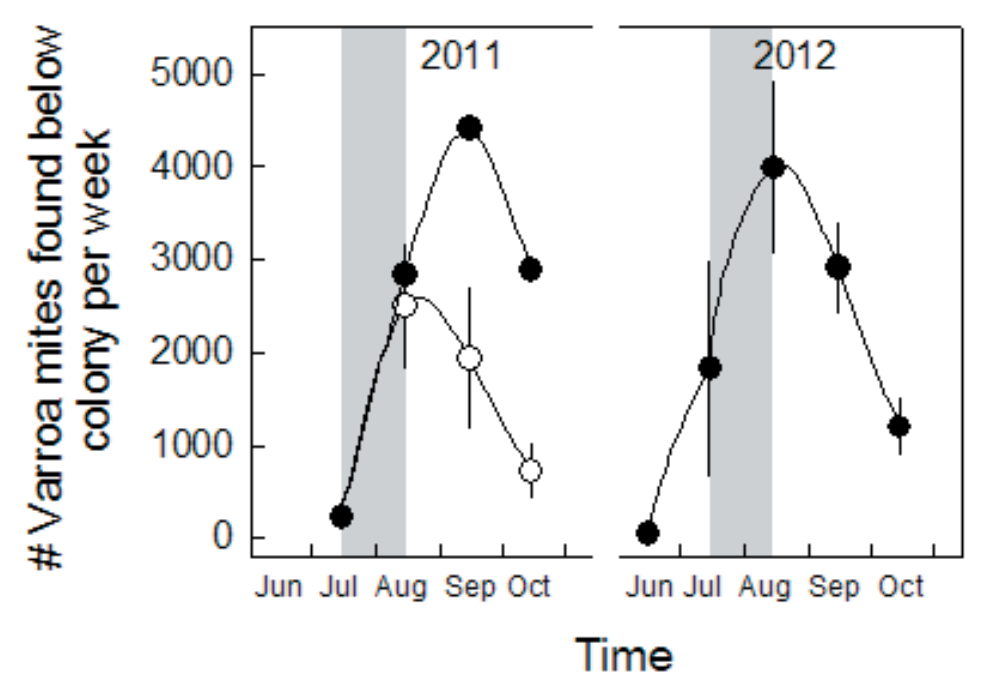

Fig. 4. Time course of the number of varroa mites found per week below the managed honey bee colonies that died $(\cdot)$ and survived $(\circ)$ in the winters of 2011/2012 (left) and 2012/2013 (right) at the Lorentzweiler location. In the winter of 2011/12, one colony collapsed, while 3 survived. In the winter of 2012/2013, the 3 remaining colonies died. Points were connected with a spline interpolation. Periods of varroa control are indicated by grey shading. 


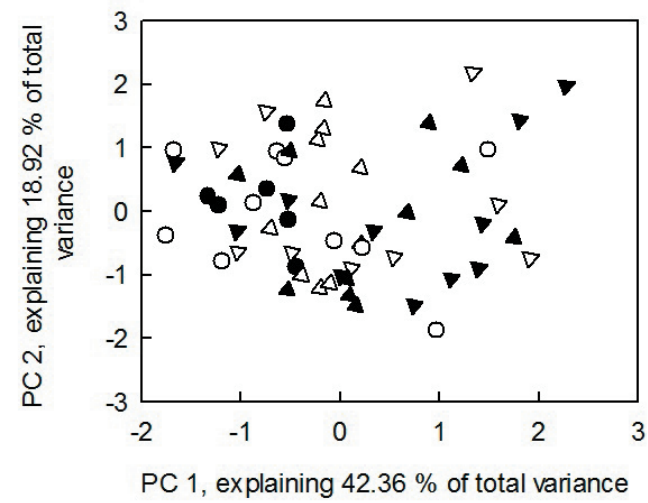

$\begin{array}{lcc}\text { Sampling period } & \text { dead } & \text { alive } \\ \text { July } 2011 & \bullet & 0 \\ \text { July } 2012 & 4 & \Delta \\ \text { August } 2012 & \nabla & \nabla\end{array}$

Fig. 5. Principal components (PCs) explaining most of the variance in the bee virus data plotted against each other. Colonies that survived the monitoring period are indicated by white symbols, colonies that died are indicated by black symbols. Circles represent samples taken in July 2011. Triangles facing up represent samples taken in July 2012 and triangles facing down represent samples taken in August 2012.

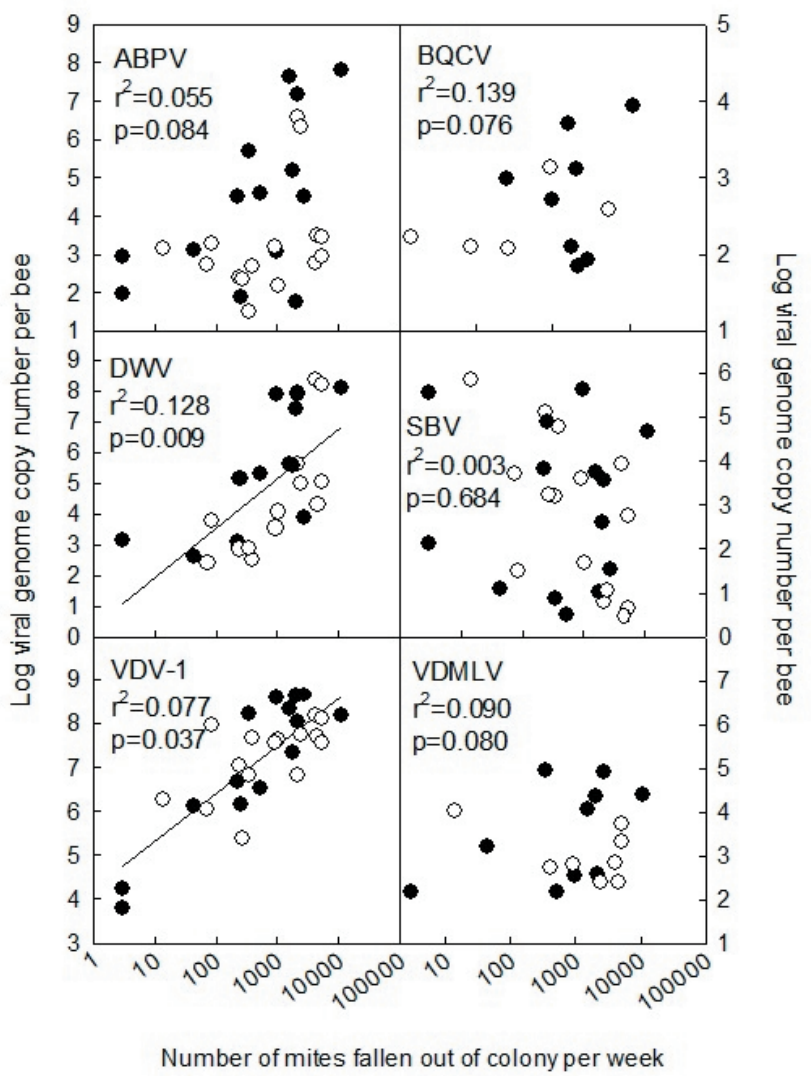

Fig. 6. Common logarithm of the average number of viral genome copy numbers per bee plotted against the number of varroa mites that have fallen out of the colony per week. Filled circles $(\bullet)$ indicate colonies that died in the winter after sampling, open circles ( $\left.{ }^{\circ}\right)$ indicate colonies that survived the following winter. Slightly different numbers of data points were caused by the fact that some viruses were not detected in all samples. Linear regressions with a slope parameter being significantly different $(p<0.05)$ from 0 are indicated by a solid line. 
all locations. Since colony losses differed strongly among locations, we felt that a comparison of varroa levels of survivors and colonies that died from the same location should also be done, to rule out a potential bias caused by the different locations.

The apiary at Lorentzweiler was most suitable for this purpose, because both, colonies that died as well as colonies that survived, were observed at this location. Furthermore, a complete set of the varroa samples was available. At this location, one out of four colonies died over the winter of 2011/2012. More than 4000 varroa mites were collected per week on the varroa board below this colony in September 2011. Whereas the maximum number of mites found per week on varroa boards below the surviving colonies was about 2500 , recorded in August (Fig. 4). The three surviving colonies from 2011 died during the winter of 2012/2013. The time-course of varroa mites found below the colonies closely resembled the time-course of the dead colony of the previous year, except that the peak of about 4000 mites per week was observed approximately one month earlier in 2012 compared to 2011 (Fig. 4).

\section{Virus loads and survival}

The virus levels detected in colonies that survived the winter after sampling and those that did not survive were not significantly different, except for SBV. On average, SBV levels were slightly higher in colonies that survived. The principal components extracted from the bee virus contents clearly overlapped each other (Fig. 5). This finding means that surviving colonies could not be separated from colonies that died based on their virus combinations and virus contents in summer. However, at the Heinerscheid location, where all colonies were lost in both years, the highest virus levels within the present study were observed for ABPV, BQCV, and VdMLV in individual colonies (Tab. 1).

\section{Virus loads and varroa mites}

Virus content data as well as varroa count data were approximately log-normally distributed. Hence, data of both variables were log-transformed prior to further processing. Log-transformed virus contents and varroa counts from the same sampling periods were either positively correlated (VDV-1: $p<0.001$, DWV: $p=0.001$ ) or statistically independent (all other viruses, fig. 6). The contents of DWV were, on average, higher in colonies that died compared to colonies that survived (Fig. 6), but the difference was non-significant.

\section{DISCUSSION}

We have determined bee virus levels in Luxembourgish apiaries for the first time and found a high prevalence of a rather homogenous set of viruses, in all the apiaries sampled.

\section{Regional aspects}

Although the loss rates were higher in the experimental colonies of the present report, the general pattern of elevated losses in the North and lower losses in the South was consistent with a recent nation-wide survey (Fig. 1, Clermont et al., 2014). Even though the highest virus levels within the present study for ABPV, BQCV, DWV, and VdMLV were observed at the northern Heinerscheid location, where all colonies were lost in both years surveyed, no significant differences towards other locations could be demonstrated as far as these viruses were concerned. Interestingly, high SBV levels were, on average, found in the apiary at Linger, where no colonies were lost in the observation period. The VdMLV was found in 34 out of 56 samples distributed over all locations with variable prevalence and no obvious relation to colony survival. There were low levels of VDV-1 at Rolling and Linger, moderate at Lorentzweiler and Reichlange, and high at Heinerscheid, and reflected the varroa levels found at the locations (Tab. 3).

Tentcheva et al. (2004) found DWV, SBV, ABPV, $B Q C V, K B V$, and CBPV in neighbouring France, in honeybees sampled in 2002. In Germany, ABPV, DWV, and SBV were found at frequencies > 4.4\% between the years 2004 and 2007, whereas KBV was rarely found. In contrast to Denmark (Francis and Kryger, 2012) and Poland (Pohorecka et al., 2011), IAPV was not found at all (Genersch et al., 2010). Ravoet et al. (2013) recently confirmed the presence of Aphid Lethal Paralysis Virus (ALPV) and VdMLV in Belgium. De Smet et al. (2012) reported ABPV, BQCV, CBPV, DWV, and SBV from bees sampled in 2011, in Northern Belgium, while SBPV was not found. De Graaf et al. (2008) found VDV-1 in Belgium. In Luxembourg, KBV was previously found (Siede et al., 2005), and traces of it were found sporadically in 2 colonies from 2 locations, suggesting that this virus rarely occurs. Our results confirm the presence of DWV, SBV, BQCV, VDV-1, and ABPV in the Benelux region. The rare occurrence of KBV and no evidence for the presence of IAPV as was previously reported from Germany, were also confirmed for Luxembourg. In contrast to France (Tentcheva et al., 2004) and Belgium (De Smet et al., 2012), CBPV was not found in Luxembourg, so far. In our samples, SBPV could 
not be detected nor could SBPV be detected in the Belgian study by De Smet et al. (2012). Thus, SBPV may, at present, be absent in the Benelux region.

\section{Evidence for virus-varroa interactions}

Previous studies found associations between varroa mites and ABPV, KBV, BQCV, DWV, VDV-1, and VdMLV (de Miranda et al., 2013). Our data confirm a close association of varroa mites with VDV-1 and DWV levels (Fig. 6). Also, positive, though not significant trends were observed between varroa levels, ABPV and BQCV (Fig. 6). For SBV, where the association with varroa mites is, at present, uncertain (de Miranda et al., 2013), our data support the hypothesis of no relationship or even a negative relationship (Fig. 6). SBV has no major consequences for colony survival in $A$. mellifera (Blanchard et al., 2014). Since both, SBV and varroa mites need bee larvae for propagation, it might be speculated that this competition may (1) prevent high SBV and high varroa levels in the same colonies at the same time, and (2) result in slightly higher SBV levels in surviving colonies compared to lost colonies, as was observed in the present study. In contrast to previous reports, we did not find an association between varroa levels and VdMLV (Fig. 6). Since VdMLV was not found in all apiaries, the number of replicates was lower than for the other viruses, and thus, the absence of a correlation between VdMLV and varroa levels should be interpreted with caution.

\section{Virus and varroa levels and colony survival}

The fact that survivors and the colonies that died always overlapped in Fig. 6 indicates that virus levels (of the viruses assayed here) from July and August are not sufficient to draw reliable conclusions about the survival of the colonies over the next winter. In contrast, the impact of varroa mites on survival was obvious in both years surveyed (Fig. 3, 4; Tab. 3).

\section{A critical evaluation of the methods used}

Previous publications indicated that at least about 5000 workers are needed to maintain a temperature above $18^{\circ} \mathrm{C}$ in broodless bee clusters. This is the temperature which is needed to survive winter in central and northern Europe (Seeley, 1985; Moritz and Southwick, 1992). In our experiments, colonies did not survive if the temperature in the hives dropped below $14^{\circ} \mathrm{C}$. But we cannot rule out that the bee clusters in our experimental hives moved over time. Also, the temperature sensor initially mounted at the centre of the cluster may not have been positioned exactly in the centre of the cluster over the entire period of measurement. Thus a somewhat lower temperature could have been measured from the sensor at the periphery of the bee cluster.

According to the standard methods for virus research in Apis mellifera described in the colOSS bee book (de Miranda et al., 2013), our experiment falls into the class of active surveillance. Our results, therefore, are not biased by beekeeper interest and knowledge. However, due to the different distances from the diagnostic facility, the samples from the locations differed concerning their transport times. To avoid virus decomposition, bees were transported while alive, in a cool box. The bees used for virus analyses in the present study were sampled on sunny afternoons, when many foraging bees were flying from a frame located at the periphery of the colony, to avoid sampling the queen. Those frames usually preferentially contain honey and pollen stocks which are taken care of by medium-aged bees. This means that the virus results presented here reflect the virus status of medium-aged bees rather than that of young nursing or older foraging bees. Between the 2 sampling periods of 2012, there was a temporal distance of approximately one month, allowing for the renewal of the bees.

We found a higher virus prevalence compared to the large scale screening in neighbouring Germany (Genersch et al., 2010). Potential technical explanations for this difference include a higher sensitivity of the method used in our study. For instance, Kirsanow et al. (2010) demonstrated that SYBR green detection was 3 to 8 times more sensitive than ethidium bromide detection. Furthermore, we used 25 bees per sample whereas Genersch et al. (2010) used 10 bees, further increasing the chance that we would detect lower virus levels. Based on the present data, we cannot decide whether we found a higher prevalence than Genersch et al. (2010) because we used a more sensitive technical approach, or, if there was a higher prevalence in Luxembourg compared to Germany. It may be argued that even 25 bees per sample are not sufficient to draw reliable conclusions about virus prevalence in a colony. Even though this argument may be valid for theoretical reasons it applies only to some viruses in the present study. At all the sampling times, SBV and VDV were found in all the colonies, and thus, a higher prevalence cannot be expected for these viruses no matter how large the sample size. In all the colonies, DWV and ABPV were found, even though not at all sampling times at levels above the detection limit. Again, prevalence at the colony level was $100 \%$ and increasing the sample size could not 
have increased the prevalence at the colony level. Higher virus prevalence at the colony level due to increased sample size was thus, only possible for the other viruses.

Since no apiaries free of BQCV, VDV-1, and SBV were found, conclusions concerning loss rates in their absence cannot be drawn. Genersch et al. (2010) found significant differences between colonies that survived and colonies that died as far as the occurrence of ABPV and DWV were concerned. But we did not find a relationship between virus content and survival in these cases. It must be kept in mind, that almost all our colonies contained ABPV and DWV (Tab. 1), which means we examined an almost completely infected sub-population. Sufficient replicates for comparing with presumably virus free colonies were lacking. We cannot rule out that the viruses detected here contributed to losses, but due to their rather homogenous distribution to a similar degree in all apiaries. It is also possible that higher virus levels than found here are needed to detect a clear connection with colony survival.

The following viruses: ABPV, KBV, and IAPV are part of a complex of closely related viruses from the family Dicistroviridae. Deformed wing virus and VDV-1 belong to the group of iflaviruses. Due to the high level of similarity within these groups, the risk of confounding within the groups is larger compared to the risk of confounding between different virus groups. If the primers used here would not have been able to distinguish, for instance, between DWV and VDV-1, virus levels should have been approximately the same for both viruses. Hence, an almost perfect correlation between the amounts expressed in ng should have been obtained. This was not the case. The p-value for the relationship between DWV and VDV-1 levels expressed as ng was 0.21, the coefficient of correlation 0.17 . So, we have no reason to assume that the primers used for DWV and VDV-1 were unable to distinguish these closely related viruses. For ABPV, we could not test for correlations with KBV or IAPV levels, because the latter 2 viruses were not found at amounts above the quantification level.

Given the fact that varroa control treatments in summer were done according to a strict standard scheme between the $15^{\text {th }}$ of July and the $15^{\text {th }}$ of August, treatments may have been too late in 2012 (Fig. 4, 5), contributing potentially to the elevated colony losses in the winter of 2012/2013.

\section{CONCLUSIONS}

We were the first to report bee virus levels of BQCV, VDV-1, SBV, VdMLV, DWV, and ABPV from Luxembourg. In contrast to the virus composition, varroa levels differed regionally and were related to colony losses. These findings suggest that varroa levels were more important for explaining the bee colony losses recently reported (Clermont et al., 2014) than the virus composition at the virus levels found in the present study. We could not detect SBPV in any of our samples nor in the Belgian study by De Smet et al. (2012). Such a lack of detection means that SBPV may be absent in the Benelux region. In surviving colonies, SBV levels were slightly higher compared to lost colonies, and independent of varroa levels. This suggests a neutral or competitive relationship between this virus and varroa mites. In contrast to France and Belgium, CBPV has not yet been found in Luxembourg.

\section{ACKNOWLEDGEMENTS}

We extend our thanks to the 'Administration des Services Techniques de l'Agriculture' of Luxembourg for the financial support of the project Beefirst, and to Joachim de Miranda (Swedish University of Agricultural Sciences) for providing reference materials and critical comments on the manuscript. We also wish to thank George Gidt, Nico Turmes, Marcel Straus, Christian Schanck, Roger Dammé, and Fränz Kutten for their technical support, two anonymous reviewers for their comments, and Wulf Menzel (DSMZ) for advice concerning virus systematics.

\section{REFERENCES}

Blanchard P., Guillot S., Antùnez K., Köglberger H., Kryger P." De Miranda J. R., Franco S., Chauzat M.-P., Thiéry R., Ribière M. (2014) Development and validation of a real-time two-step RT-qPCR TaqMan $\left({ }^{\oplus}\right)$ assay for quantitation of Sacbrood virus (SBV) and its application to a field survey of symptomatic honey bee colonies. Journal of Virological Methods 197: 7-13. DOl: 10.1016/j. jviromet.2013.09.012

Chen Y. P." Pettis J. S., Collins A., Feldlaufer M. F. (2006) Prevalence and transmission of honeybee viruses. Applied and Environmental Microbiology 72: 606-611. DOl: 10.1128/AEM.72.1.606-611.2006 


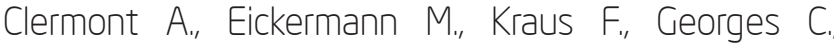
Hoffmann L., Beyer M. (2014) A survey on some factors potentially affecting losses of managed honeybee colonies in Luxembourg over the winters 2010/2011 and 201 1/2012. Journal of Apicultural Research 53: 4356. DOl: 10.3896/IBRA.1.53.1.04

Dainat B., Evans J. D., Chen Y. P., Gauthier L., Neumann P. (2012) Dead or alive: Deformed wing virus and Varroa destructor reduce the life span of winter honeybees. Applied and Environmental Microbiology 78: 981-987. DOl: 10.1128/AEM.06537-11

De Graaf D. C., Brunain M., Imberechts H., Jacobs F. J. (2008) First molecular confirmation of deformed wing virus infections of honeybees from a Belgian apiary reveals the presence of black queen cell virus and Varroa destructor virus 1. Vlaams Diergeneeskundig Tijdschrift 77: 101-105.

de Miranda J. R., Bailey L., Ball B. V., Blanchard P., Budge G. E., Chejanovsky N., Chen Y.-P., Gauthier L., Genersch E., de Graaf D. C., Ribière M., Ryabov E., De Smet L., van der Steen I. I. M. (2013) Standard methods for virus research in Apis mellifera. Journal of Apicultural Research 52: 1 - 16. DOl: 10.3896/IBRA. 1.52.4.22

De Smet L., Ravoet I., De Miranda J. R., Wenseleers T., Mueller M. Y., Moritz R. F. A., de Graaf D. C. (2012) BeeDoctor, a versatile MPLA-based diagnostic tool for screening bee viruses. PLoS ONE 7: e47953. DOl: 10.1371/journal.pone.0047953

Dwight Z., Palais R., Wittwer C. T. (2011) UMELT: prediction of high-resolution melting curves and dynamic melting profiles of PCR products in a rich web application. Bioinformatics 27: 1019-1020. DOl: 10.1093/bioinformatics/btr065

Francis R. M., Kryger P. (2012) Single assay detection of Acute Bee Paralysis Virus, Kashmir Bee Virus and Israeli Acute Paralysis Virus. Journal of Apicultural Science 56: 137-146. DOl: 10.2478/v10289-012-0014-x

Francis R. M., Nielsen S. L., Kryger P. (2013) Varroa-virus interaction in collapsing honey bee colonies. PLoS ONE 8: e57540. DOl: 10.1371/journal.pone.0057540

Gallai N., Salles J. -M., Settele J., Vaissière B. E. (2009) Economic valuation of the vulnerability of world agriculture confronted with pollinator decline. Ecological Economics 68: 810-821. DOl: 10.1016/j. ecolecon.2008.06.014
Gauthier L., Ravallec M., Tournaire M., Cousserans F., Bergoin M., Dainat B., De Miranda J. R. (2011) Viruses associated with ovarian degeneration in Apis mellifera L. Queens. PLoS ONE 6: e16217. DOl: 10.1371/journal. pone.0016217. D0l: 10.1371/journal.pone.0016217

Genersch E. (2010) Honey bee pathology: current threats to honey bees and beekeeping. Applied Microbiology and Biotechnology 87: 87-97. DOI: 10.1007/s00253-0102573-8

Genersch E., von der Ohe W., Kaatz H., Schroeder A., Otten C., Büchler R., Berg S., Ritter W., Mühlen W., Gisder S., Meixner M., Liebig G., Rosenkranz P. (2010) The German bee monitoring project: a long term study to understand periodically high winter losses of honey bee colonies. Apidologie 41: 332-352. DOl: 10.1051/apido/2010014

IBM SPSS Statistics for Windows, Version 19.0 (2010) IBM Corp. Armonk, NY.

Kirsanov K. I., Lesovaya E. A., Yakubovskaya M. G., Belitsky G. A. (2010) SYBR Gold and SYBR Green II are not mutagenic in the Ames test. Mutation Research 699: 1-4. DOl: 10.1016/j.mrgentox.2010.04.014

Li Z., Chen Y., Zhang S., Chen S., Li W., Yan L., Shi L., Wu L., Sohr A., Su S. (2013) Viral infection affects sucrose responsiveness and homing ability of forager honey bees, Apis mellifera L. PLoS ONE 8: e77354. DOl: 10.1371/ journal.pone.0077354

Locke B., Forsgren E., Fries I., De Miranda J. R. (2012) Acaricide treatment affects viral dynamics in Varroa destructor-infested honey bee colonies via both host physiology and mite control. Applied and Environmental Microbiology 78: 227-235. DOl: 10.1 128/AEM.0609411

Moritz R. F. A., Southwick E. E. (1992) Bees as superorganisms. An evolutionary reality. Springer-Verlag. Berlin. 395 pp.

Möckel N., Gisder S., Genersch E. (2011) Horizontal transmission of deformed wing virus: pathological consequences in adult bees (Apis mellifera) depend on the transmission route. Journal of General Virology 92: 370-377. DOl: 10.1099/vir.0.025940-0

Nicholls C. I., Altieri M. A. (2013) Plant biodiversity enhances bees and other insect pollinators in agroecosystems. A review. Agronomy for Sustainable Development 33: 257-274. DOl: 10.1007/s1 3593-0120092-y 


\section{Ј. APPC. SCL. VOL. 59 N NO. 12015}

Pasquali M., Piatti P., Gullinom M. L., Garibaldim A. (2006) Development of a real-time polymerase chain reaction for the detection of Fusarium oxysporum f. sp. basilici from basil seed and roots. Journal of Phytopathology 154 : 632-636. DOl: 10.1111/j.1439-0434.2006.01 160.x

Pohorecka K., Zdańska D, Bober A., Skubida M. (2011) First detection of Israeli Acute Paralysis Virus (IAPV) in Poland and phylogenetic analysis of the isolates. Journal of Apicultural Science 55: 149-159.

Potts S. G., Roberts S. P. M., Dean R., Marris G., Brown M. A., Jones H. R., Neumann P., Settele J. (2010) Declines of managed honey bees and beekeepers in Europe. Journal of Apicultural Research 49: 15-22. DOl: 10.3896/ IBRA. 1.49.1.02

Ravoet J., Maharramov J., Meeus I., Wenseleers T., Smagghe G., de Graaf D. C. (2013) Comprehensive bee pathogen screening in Belgium reveals Crithidia mellificae as a new contributory factor to winter mortality. PLoS ONE 8: e72443. DOl: 10.1371/journal.pone.0072443

Rosenkranz P." Aumeier P." Ziegelmann B. (2010) Biology and control of Varroa destructor. Journal of Invertebrate Pathology 103: S96-S1 19. DOl: 10.1016/j. jip.2009.07.016

Runckel C., Flenniken M. L., Engel J. C., Ruby J. G., Ganem D., Andino R., DeRisi J. L. (2011) Temporal analysis of the honey bee microbiome reveals four novel viruses and seasonal prevalence of known viruses, Nosema, and Crithidia. PLoS ONE 6: e20656. DOl: 10.1371/journal. pone.0020656

Scharlaken B., de Graaf D. C., Goossens K., Brunain M., Peelman L. J., Jacobs F. J. (2008) Reference gene selection for insect expression studies using quantitative realtime PCR: the head of the honeybee, Apis mellifera, after a bacterial challenge. Journal of Insect Science 8: 33. DOI: 10.1673/031.008.3301

Seeley T. D. (1985) Honeybee ecology. A study of adaptation in social life. Princeton University Press, Princeton, NJ, 216 pp.
Semkiw P., Skubida P. (2010) Evaluation of the economical aspects of Polish beekeeping. Journal of Apicultural Science 54: 5-15.

Sequence Manipulation Suite: DNA Molecular Weight (2004) Available at: http://www.bioinformatics.org/ sms2/dna_mw.html

Siede R., Derakhshifar I., Otten C., Berényi O., Bakonyi T., Köglberger H., Büchler R. (2005) Prevalence of Kashmir bee virus in central Europe. Journal of Apicultural Research 44 (3): 129-29. DOI: 10.3896/IBRA. 1.44.3.09

Tentcheva D., Gauthier L., Zapulla N., Dainat B., Cousserans F., Coling M. E., Bergoin M. (2004) Prevalence and seasonal variations of six bee viruses in Apis mellifera $L$. and Varroa destructor mite populations in France. Applied and Environmental Microbiology 70: 7185-7191. DOl: 10.1128/AEM.70.12.7185-7191.2004

van der Zee R., Brodschneider R., Brusbardis V., Charrière J. -D., Chlebo R., Coffey M. F., Dahle B., Drazic M. M., Kauko

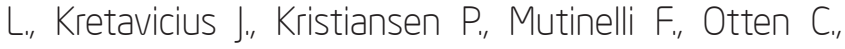
Peterson M., Raudmets A., Santrac V., Seppälä A., Soroker V., Topolska G., Vejsnæes F., Gray A. (2014) Results of international standardised beekeeper surveys of colony losses for winter 2012-2013: analysis of winter loss rates and mixed effects modelling of risk factors for winter loss. Journal of Apicultural Research 53: 19-34. DOI: 10.3896/IBRA. 1.53.1.02

vanEngelsdorp D., Caron D., Hayes J., Underwood R., Henson K. R. M., Spleen A., Andree M., Snyder R., Lee K., Roccasecca K., Wilson M., Wilkes J., Lengerich E., Pettis J. (2012) A national survey of managed honey bee 201011 winter colony losses in the USA: results from the Bee Informed Partnership. Journal of Apicultural Research 51: 115-124. DOl: 10.3896/IBRA.1.51.1.14

Winnebeck E. C., Millar C. D., Warman G. R. (2010) Why does insect RNA look degraded? Journal of Insect Science 10: 159. DOl: 10.1673/031.010.14119 